\title{
Communication Apprehension: A Comparison between English Majors and Non-majors in China
}

\author{
Peng Shi-Yong (Corresponding author) \\ College of Arts and Sciences, Abu Dhabi University \\ Abu Dhabi, P.O. Box 59911, U.A.E \\ E-mail: Sherwin_peng@yahoo.com \\ Muhamad Sham Bin S. Ali \\ College of Arts and Sciences, Abu Dhabi University \\ Abu Dhabi, P.O. Box 59911, U.A.E \\ E-mail: muhamad.sham@adu.ac.ae
}

Received: 20-04- 2015

Published: 01-11- 2015
Accepted: 25-07- 2015

doi:10.7575/aiac.ijalel.v.4n.6p.190
Advance Access Published: August 2015

URL: http://dx.doi.org/10.7575/aiac.ijalel.v.4n.6p.190

\begin{abstract}
Using the scale of communication apprehension developed by McCroskey, a comparative study has been conducted between English majors and non-majors of different English learning experiences in a Chinese university. Whereas all the subjects remain at the medium level of communication apprehension, no significant difference was found across different communication scenarios among students of different majors as well as different grades. The results imply that the cause of communication apprehension might not be necessarily associated with differences in learning experience, syllabi or even teaching approaches. The characteristics of the high-contextual Chinese culture may be interpretable to this non-difference result. Thus, we may hypothesize with confidence that psychological approaches may be more effective to reduce the phenomenon of mute English of Chinese learners and their reticence in English class.
\end{abstract}

Keywords: communication apprehension, mute English, Chinese

\section{Introduction}

\subsection{Mute English in China}

One of the perplexing inhibiting problems for Chinese English learners is the "Mute English" characterized by their inability or reluctance to speak English for basic communication proposes or to understand spoken English. Decades of English teaching practice in China indicate that mute English is a very common phenomenon or eventual learning outcome among majority of Chinese students who have learned English for years in high schools and/or in the universities (Dai, 2001, Lu, 2009, Wei, 2002, Yuan, 2007). In current Chinese higher education system, English is a compulsory course for all undergraduate and graduate programs. Students will have learned English for at least 15 years when they graduate from the university. However, most of them can neither clearly express themselves in English nor understand other English speakers (Li, 2002), much less to reach the high level of English proficiency in speaking, writing, listening or reading as demanded by the National English Curriculum.

In China, most students learn English just to pass various kinds of English tests designed as an action through the motion for career development or other pragmatic reasons. Very few of them will have chance to use English as a communication tool in the entire span of their life. Thus, it is not surprising to find college graduates with some 10 years of English learning experience unable to utter anything more than "thank you" or "how are you?" in English.

Although many Chinese scholars have been trying to find any possible means to treat mute English through attempts to improve teaching or learning approaches, this problem has never been effectively resolved. Scholars in China (e.g. Yuan, 2007) believed that the mute English is a direct consequence of examination-bound education system that has been prevailing in China, where "Chinese students and teachers are deeply influenced by the tradition of examinationoriented education in China. They care most for the examinations, and the scores of examinations are the main KPI's for teaching and learning" (Zhou, Wang, \& Wang, 2004, p.79). Some scholars (e.g. Dai, 2001) maintained that mute English is due to outdated teaching approaches overlooking the importance of communication skill development in class. Other scholars (e.g, Tang, 2005) held that the poor oral proficiency of many English teachers negatively influences students' willingness to speak English. Cai (2005) and Wang (2003) further indicated that mute English is associated with the lack of English speaking environment in China. All in all, scholars in China agree that mute English is a hard-to-treat diseases in English education in China (Cen,1999; Dai \& Wu, 2010).

It is definitely a failure of English education and huge waste of education resources that Chinese students end up in mute English after so many years of learning. However, if we cannot identify the genuine causes, thus to eliminate or 
treat to say the least, mute English, Chinese mute English will continue to dominate the English education in this country, where the nation wide process for modernization needs more talents with overall English proficiency.

This study attempts to investigate the influence of communication apprehension of Chinese English learners on their willingness to communicate in English and to find out if relationship exists between communication apprehension and different English-learning experiences so that finally we may be able to come up with clues that may lead to any functional measures to reduce or eliminate mute English effectively.

\subsection{Literature Review}

Over decades scholars in China have been looking into the problem of mute English and produced quite a lot of research output and proposed arguments over this phenomenon. For example, Tang (2005) proposed that we need to investigate the learning motivations in order to find out the solution to enhance English oral proficiency of Chinese English learners. In his study (2005), Tang discovered that the current Chinese university students have almost no motivation to learn and practice oral English. However, His study only provided descriptive data analysis. He did not conduct inferential analysis to explore any possible relationships between variables that may influence learning motivation of the students. The results of this study are very weak and do not provide any strong interpretation of the mute English phenomenon in China.

Mute English and deaf English are twins because "most mute English learners are also deaf to spoken English" (Wang, 2010 , p.18). For years, scholars of Chinese origin both at home and abroad have been proposing various solutions. For example, Cai (2005) and Zhang (2003) held that foreign language learning should emphasize the training of listening comprehension and oral communication ability. Others scholars (Dai, 2009, Gao, 2003) suggested that we should deemphasize examinations in English teaching. Still other scholars (Rang, 2006; Yu \& Wang, 2003) criticized the classroom teaching practice and national curriculum of English learning. Given all the efforts to analyze the possible causes of mute English that has been perplexing foreign language teaching since 1960s (Gui, 2005), we have not yet found any effective treatment although various means have been proposed.

Among all the solutions to mute English, communicative teaching approach proposed by Chinese scholars was very popular in the 1990s. During the entire 90s, this approach was once hailed as a "breakthrough" to mute English (Zhang, 2010). However, in fact, this approach has never been an effective treatment to mute English. Chinese students are still well-known to be mute in English.

In 2007, Chinese Ministry of Education proclaimed the revised National English Curriculum of University where the basic requirement is still "the development of students' comprehensive practical skills of English" (p.1). However, given all the reasons for mute English scholars have so far identified, one unadmitted reason is that many English teachers themselves in Chinese universities are not able to speak English fluently. Some of them even have far poorer oral communicative ability than their students in their class, although they may hold a PhD degree (Peng, 2002). Some of them can only speak a few English sentences needed for classroom management. Studies (Li, 2001; Zan, 2010) showed that the foreign language proficiency of the teachers as well as their interpersonal skills have a profound impact on their students.

In China, factors behind mute English are of complex nature, including curriculum (Sun \& Jin, 2010), teaching approach (Yue, 2002), learning interest (Hu \& Cai, 2010), learning motivation (Liu \& Gao, 2010), language environment (McPherson, 2007), personality (Jelinek \& Scheibner-Herzig, 1978), learning capability (Perani, 2005; Rees, 1972), Willingness to communicate (Leger \& Storch, 2009), or even Chinese cultural influence (Horwitz, 1999).

Chinese students are widely known to be reserved in class (Meng, 2009). It is not surprising that they are not willing to communicate in English given their low WTC even in their native Chinese language. Therefore, in addition to the inappropriate teaching method and lack of learning motivation, their unwillingness to communicate in English may be due to the fact that they have absolutely no desire to speak English at all, or they might suffer from communication apprehension or low level of WTC. Till now, very few research can be found in WTC and communication apprehension in Chinese context, whereas these are, to a large extent, influenced by cultural values (e.g.,Knutson, Komolsevin, Chatiketu \& Smith , 2002 ), which definitely have a direct impact on students' willingness to communicate in foreign languages

After decades of foreign language teaching and research, the mute English of Chinese is still a very noticeable fact, and the situation has not improved at all. If we turn our attention to the characteristics of Chinese communication, we might be able to find the contributing factors of mute English of Chinese students, thus providing therapeutic clues for mute English.

This study focuses on an important variable in communication, communication apprehension, and its impact on Chinese students during their process of English learning, especially the process of oral English acquisition. Language communication is an important communication mode of interpersonal communication. According to Horwitz and Cope (Horwitz, Horwitz, \& Cope, 1986,127), communication apprehension is a "type of shyness characterized by a fear of or anxiety about communicating with people". Communication scholars (Beatty \& Andriate, 1985; Daly, 1991; June \& McCroskey, 2004) provided a conceptual framework that defines communication apprehension as the fear occurring during the communication in one's mother tongue. Afterwards it has been widely used in international research of foreign language acquisition (e.g., Koul et al,2009; Matsuoka \& Rahimi, 2010) because the process of foreign language 
acquisition may produce or increase communication apprehension (June \& McCroskey, 2004. Additionally, in the field of applied linguistics research communication apprehension and language anxiety are highly associated (Arnold, 2007).

Literature indicates foreign language learners under communication apprehension have a very low willingness to communicate in foreign languages. Their typical behavior is to avoid communicating in foreign language (MacIntyre \& Charos, 1996). This is very similar to Chinese English learners. Thus, we are confident to hypothesize that Chinese students suffer from different degrees of communication apprehension when they communicate in English. This current study investigated the levels of communication apprehension of Chinese English major and non-major students with different English learning experience. Hopefully, this study can find out the impact of communication apprehension on the learning process of Chinese students.

\section{Method}

\subsection{Measurement Scale}

This study applied the Personal Report of Communication Apprehension developed by McCroskey (1982). This scale measures the levels of communication apprehension in four distinct situations. These situations include group discussions, meetings, interpersonal conversations, and public speeches. All of the measurements are 5-point Likert scales. For example,

Group discussions: I dislike participating in group discussions.

Meetings: Usually, I am comfortable when I have to participate in a meeting.

Interpersonal conversations: I have no fear of speaking up in conversations.

Public speeches: I have no fear of giving a speech.

This scale categorizes communication apprehension into 3 levels:

$\begin{array}{llll}\text { Group discussions: } & \text { high }>20 ; & \text { low }<11 ; & \text { medium between } 11 \text { and } 20 \\ \text { Meetings: } & & \text { high }>20 ; & \text { low }<13 ; \text { medium between } 13 \text { and } 20 \\ \text { Interpersonal conversations: } & \text { high }>18 ; & \text { low }<11 ; & \text { medium between } 11 \text { and } 18 \\ \text { Public speeches: } & \text { high }>24 ; & \text { low }<14 ; & \text { medium between } 14 \text { and } 24 \\ \text { Total score } & \text { high }>80 ; & l o w<51 ; & \text { medium between } 51 \text { and } 80\end{array}$

\subsection{Data Collection}

Data for this study was collected in Guangzhou University, China. MANOVA was performed to compare the communication apprehension among students of different grades to identify possible differences in communication apprehension caused by different English learning experiences. Students of different majors were also compared to identify the possible impact of different teaching approaches, course materials and learning outcomes on the levels of communication apprehension.

\section{Results}

3.1 Data Analysis

One-way ANOVA was performed for the data analysis, and the results are presented $\mathrm{n}$ the following tables.

Table 1. Comparison among Different Grades of Students

\begin{tabular}{ccccc}
\hline Scenarios & $\begin{array}{c}1^{\text {st }} \text { Year } \\
\mathrm{n}=196\end{array}$ & $\begin{array}{c}2^{\text {nd }} \text { Year } \\
\mathrm{n}=107\end{array}$ & $\begin{array}{c}3^{\text {rd }} \text { Year } \\
\mathrm{n}=91\end{array}$ & $\begin{array}{c}4^{\text {th }} \text { Year } \\
\mathrm{n}=67\end{array}$ \\
\hline Group discussion & $15.0_{\mathrm{a}}$ & $15.3_{\mathrm{a}}$ & $14.5_{\mathrm{a}}$ & $14.6_{\mathrm{a}}$ \\
Meeting speech & $17.9_{\mathrm{a}}$ & $17.8_{\mathrm{a}}$ & $18.5_{\mathrm{a}}$ & $18.7_{\mathrm{a}}$ \\
Interpersonal & $14.3_{\mathrm{a}}$ & $14 . \mathrm{a}_{\mathrm{a}}$ & $14.6_{\mathrm{a}}$ & $14.4_{\mathrm{a}}$ \\
communication & & & & \\
Public speaking & $17.7_{\mathrm{a}}$ & $17.1_{\mathrm{a}}$ & $17.8_{\mathrm{a}}$ & $17.9_{\mathrm{a}}$ \\
Total & $64.9_{\mathrm{a}}$ & $65.3_{\mathrm{a}}$ & $65.4_{\mathrm{a}}$ & $65.6_{\mathrm{a}}$ \\
\hline
\end{tabular}

Note: the same subscripts in rows indicate no significant differences at $p<0.05$ with Student-Newman-Keuls Test.

The results in table 1 indicate that there are significant differences across students of different majors in their communication apprehension and their communication apprehensions under the four situations as well as their total communication apprehensions are at medium level. 
Table 2. Comparison among Students of Different Majors

\begin{tabular}{lccc}
\hline \multicolumn{1}{c}{ Scenarios } & $\begin{array}{c}\text { English } \\
\mathrm{n}=311\end{array}$ & $\begin{array}{c}\text { Humanities } \\
\mathrm{n}=84\end{array}$ & $\begin{array}{c}\text { Sciences } \\
\mathrm{n}=66\end{array}$ \\
\hline \multicolumn{1}{c}{ Group discussions } & $14.8_{\mathrm{a}}$ & $14 . \mathrm{a}_{\mathrm{a}}$ & $15.8_{\mathrm{a}}$ \\
Meetings & $18.4_{\mathrm{a}}$ & $17.3_{\mathrm{a}}$ & $17.7 \mathrm{a}$ \\
Interpersonal & $14.3_{\mathrm{a}}$ & $13.9_{\mathrm{a}}$ & $14.9 \mathrm{a}$ \\
Conversations & & & \\
& & & $17.2_{\mathrm{a}}$ \\
Public Speeches & $17.8_{\mathrm{a}}$ & $17.4_{\mathrm{a}}$ & $65.6_{\mathrm{a}}$ \\
Total & $65.3_{\mathrm{a}}$ & $63 . \mathrm{a}_{\mathrm{a}}$ & \\
\hline
\end{tabular}

Note: the same subscripts in rows indicate no significant differences at $p<0.05$ with Student-Newman-Keuls Test.

The results in Table 2 are consistent with the results in table 1. No significant differences are found among students majoring in English, humanities, and sciences. Their communication total apprehension is at medium level, and so are their communication apprehension levels under the four different scenarios.

\section{Discussion \& Conclusion}

The overall results of this study clearly indicate that most probably it is the cultural factors that caused the communication apprehension of Chinese students while they communicate in English. The fact that English major students and non-major students have the same level of communication apprehension possibly indicate that teaching approaches, course materials did not seem to have any significant impact on the reduction of communication apprehension. This leads us to understand why Chinese students are afraid of speaking English in class or outside class, and why over the past decades, educators have not yet found any effective solutions to treat the mute English because they have not identified the underlying cause.

The results of this hint us that attempts to eliminate or reduce mute English by changing course materials or teaching approaches will not be of any significant help if mute English of Chinese students is due to cultural reasons. Chinese culture is high contextual characterized by reluctance of Chinese people to initiate communication with strangers (TingToomey, 1998). Traditional Chinese culture frowns upon talkative persons, for example, as some popular Chinese proverbs go, "evil comes out of mouth", "The least say the better", and "only tell others $30 \%$ of your mind." Chinese, of course, are very particular about face maintenance, and they would feel very embarrassed if they are found to have made mistakes when speaking English. Researchers (e.g,Bond \& Lee, 1981; Wierzbicka, 1996) have looked into the face maintenance and its related issues. However, not much can be found about the relationship between Chinese face and foreign language speaking.

The overall data analysis seems to prove that the unwillingness of Chinese students to speak English should not be attributed to their lack of learning motivation, learning interest or the improper teaching approaches. We can no doubt say that these factors do have impact on foreign language learning, but the problem regardless of all the studies and publications on foreign language learning, mute English in China is still as alive as before. Now it might be the right time for us to change the perspective of foreign language related research and look into the deep-seated problems that have been frustrating both teachers and students in China.

Foreign-language learning is not only a process of acquiring linguistic competence, but also a process of acculturation when learners should also adapt to the communication styles of the culturally different others and at the same time unlearn the possible communication barriers caused by the learners' culture. This current study did not propose any effective strategy to eliminate mute English of Chinese students, but it is obviously possible that solutions might be found if we no longer limit our attention to pedagogical methods or course materials. For example, reduction of communication apprehension as well as of fear of making mistakes in communicating in English may be able to help us treat the mute English syndrome among Chinese English learners. We can engage students in public speaking training even in Chinese language to reduce their overall stage fright and fear of making mistakes in communication.

Ultimately, to address mute English, we need to think out of the black box of foreign language teaching and try out best to explore possibilities outside classroom teaching. In way or another, we may find the answer is just at the corner.

\section{Sponsoring information}

The Research Council and Al Buraimi University College, the Sultanate of Oman.

\section{References}

Arnold, N. (2007). Reducing foreign language communication apprehension with computer-mediated communication: A preliminary study. System, 35, 470-486. 
Beatty, M.J.,\& Andriate, G.S. (1985). Communication apprehension and general anxiety in the prediction of public speaking. Communication Quarterly, 33(3), 174-184.

Bond, M., \& Lee, P. (1981). Beyond the Chinese face. Oxford University Press.

Cai, J. G. (2005). Some thoughts on college English teaching. Foreign Language Teaching and Research,37(2),83-91.

Cai, J.G. (2010).Relocation and reflections of college foreign language teaching in China. Foreign Language Teaching and Research, 42(4),306-308.

Cen, J.J. (1999). The status quo of foreign language teaching at tertiary level. Foreign Language Teaching and Research, 117(1),3-6.

Dai, W.D. (2001).Time-wasting and low efficiency of foreign language teaching. Foreign Languages and Their Teaching, 147(7),1,32.

Dai, W.D.(2009).Three decades of college foreign language teaching in China. Foreign Language World, 130(1),2-4.

Dai, W.D.,\& Wu, F.(2010).On the development of foreign language studies in China: Constraints and strategies. Foreign Language Teaching and Research, 42(3),170-175.

Daly,J.(1991).Understanding communication apprehension: An introduction for language educators. In: Horwitz, E.K., Young, D.Y. (Eds.),Language anxiety: From theory and research to classroom implications (pp.3-13). Englewood Cliffs, NJ: Prentice-Hall.

Gao,Y.(2003).Scientific foundation and Open-mind Perspective on foreign language teaching. Foreign Languages and Their Teaching, 3,222-223.

Gui, S.C. (2005). On current Foreign Language Teaching. Foreign Language in China, 3(1),5-8.

Horwitz, E.L.(1999). Cultural and situational influences on foreign language learners' beliefs about language learning: a review of BALLI studies.System,27(4), 557-579.

Horwitz, E.K., Horwitz, M.B. \& Cope, J. (1986). Foreign language classroom anxiety. Modern Language Journal, $70(2), 125-132$.

Hu,W.X., \& Cai,J.T.(2010).Modeling of English learning motivation declining. Foreign Language Education, 31(3),4149.

Jelinek, G. \& Scheibner-Herzig, G. (1978).Investigation into foreign language skills and pupil personality. System, 6(3), 173-186.

Jing. S.H.(1999). Reasons of time-wasting and low efficiency of college English teaching in China. Foreign Language Teaching and Research, 1,21-23.

June,H.Y.,\& McCroskey,J.C.(2004).Communication apprehension in a first language and self-perceived competence as predictors of communication apprehension in a second language: A study of speakers of English as a second language.Communication Quarterly, 52(2), 170-181.

Knutson, T. J, Komolsevin, R., Chatiketu, P., \& Smith, V. R. (2002).A comparison ofThai and U.S. American willingness to communicate. Journal of International Communication Research, 31(1), 3-12.

Koul, R.,Roy,L.,Kaewkuekool, S.,\& Ploisawaschai,S. (2009).Multiple goal orientations and foreign language anxiety, System,37(4),19-36.

Leger, D.S.\& Storch, N. (2009). Learners' perceptions and attitudes: Implications for willingness to communicate in an L2 classroom. System,37, 269-285.

Li, J.F.(2001).A new perspective of college English teaching methodologies. Foreign Languages and Their Teaching, 143(3), 26-28.

Li, Q.Y.(2002).Problems and Reflection on CET band 4 and Band 6. Foreign Language Education, 23(5),33-38.

Liu,L., \& Gao, Y.H.(2010). A longitudinal Study of English learning motivation and the change of self-identification. Foreign Languages and Their Teaching, 25(1),18-21.

Lu. L.(2009). Investigation of non-major MA student on their status of English learning. Foreign Language Education, 30(6), 80-83.

MacIntyre, P.D., \& Charos, C. (1996).Personality, attitudes, and affect as predictors of Second language Communication. Journal of Language and Social Psychology, 15(1), 3-26.

Matsuoka, R., \& Rahimi, A.(2010). The positive effect of conference participation on reducing L2 communication apprehension. Procedia, 9,898-907.

McCroskey, J. C. (1982).An introduction to rhetorical communication (4th Ed) Englewood Cliffs, NJ: Prentice-Hall.

McPherson, M. M. (2007).analysis of structures and roles of language learning advisers. System, 35,66-92.

Meng, F.S. (2009). Study of Reticence in College English class: A perspective of constructivism. ForeignLanguage Education, 30(4),71-74.

Peng, S.Y. (2002). The three Achilles heels of Chinese Higher Education, South Window, Oct,26-29. 
Perani, D. (2005). The neural basis of language talent in bilinguals. Trends in Cognitive Science, 9(5),211-213.

Rang,Y. P.(2006). Personal view of foreign language learning: A pragmatic perspective. Foreign Language Research, 95(1),48-51.

Rees, N.S. (1972). A talent for language. Journal of Communication Disorder, 5(2), 132-141.

Sun, Y.Z., \& Jin, L.M. (2010). Preliminary exploration of major course structure of English program. Foreign Language Teaching and Research, 42(4),303-305.

Tang,L.W.(2005).Analysis of impacting factors on the learning of oral English. Foreign Language Education,6(2),6567.

Ting-Toomey, S. (1998). Communicating effectively with the Chinese. Sage Publications Inc.

Wang, Q. M. (2003). Exploration on the linguistic input and output in college English teaching. Foreign Languages and Their Teaching, 24(3),66-69.

Wang, C.M.(2010). Reform of college English teaching and testing: A perspective of foreign language learning. Foreign Language World, 136(1),17-22.

Wei, Z.H. (2002).Summary of overseas research on factors of parole fluency of second languages. ForeignLanguage Education,23(3),18-21.

Wierzbicka, A. (1996).Contrastive sociolinguistics and the theory of "cultural scripts": Chinese vs. English. In M. Hellinger \& U. Ammon (Eds.), Contrastive sociolinguistics (pp.313-344). Berlin: de Gruyter.

Yu, X.H \& Wang, Y.H .(2003).Application of cooperative in English teaching. Foreign Language Education, 24(3),6365.

Yuan, Q.L. (2007).Analysis of consumer activities of English language. Foreign Languages and Their Teaching, 219(6),31-34.

Yue,S.G.(2002).Task-based language teaching: concepts, theories and applications. Foreign Language Teaching and Research, 34(5), 364-367.

Zhan, X. Jun.(2010). The Image of ELT teachers among college students: Reality and expectations. Foreign Languages and Their Teaching,3,40-44.

Zhang,S.J.(2010).Actions and reflections on foreign language teaching under the globalization. Foreign Languages and Their teaching,250(1),10.

Zhang, Z, B. (2003).On reforms of foreign language teaching in China. Journal of Foreign Languages, 146(4),1-6.

Zhou, Y.Z., Wang, H., \& Wang, Y.W.(2004). Analysis of the differences between Chinese and foreign teachers in foreign language teaching. Foreign Language Education, 25(6),77-80. 